\title{
An informetric analysis of the corruption literature based on Africa between 1990 and 200 I
}

\author{
Omwoyo B. Onyancha', \\ b_onyancha@yahoo.com
}

and

Dennis N. Ocholla

Department of Library and Information Science, University of Zululand, South Africa

docholla@pan.uzulu.ac.za

\begin{abstract}
Received: 15 $5^{\text {th }}$ September 2003
Revised: $10^{\text {th }}$ January 2004

This paper explores corruption literature as reflected in four online databases in the 12-year period from 1990 to 2001. Descriptive informetrics has been used for the analysis of the publications. The results of the study indicate that there was a remarkable increase in the number of articles from just nine in 1990 to 78 in 1999, followed by a decline in both 2000 and 200I. Although there seems to be a relationship between the number of articles and the level of corruption, the 0.370 correlation value is not significant to warrant a definite conclusion. EBSCO and its databases produced $90.3 \%$ while ISI yielded only $9.7 \%$. Magazines yielded $74.1 \%$ of the records, and journals $25.9 \%$. The researchers concentrated more on political corruption as opposed to administrative corruption. It was also observed that single authorship of publications on corruption stood at $76.4 \%$ for journals and $56.7 \%$ for magazines, while co-authored articles constituted $15.5 \%$ of journal articles and $8.5 \%$ of the magazine articles. Whereas Lotka's Law of Author Productivity applied as far as its theoretical observation is concerned, it does not apply statistically. The applicability of Bradford's Law of Scattering was confirmed.
\end{abstract}

\section{Introduction}

Corruption, defined as the abuse of office for private gain, is a phenomenon that could not be discussed publicly a few decades ago in Africa. In the words of Peter Eigen, the Chairman of Transparency International ( $\mathrm{TI}$ ), 'there is no end to the misuse of power by those in public offices and corruption levels are perceived to be as high as ever in both the developed and developing countries' (TI, 200I). The 200I Corruption Perception Index (CPI) ranks 91 countries according to their perceived levels of corruption. Bangladesh, Cameroon, Indonesia, Kenya, Nigeria and Uganda are rated as countries with high levels of perceived corruption in government and public administration, with a score of 2 or less out of 10 (see Table I). A '10' indicates a perfectly 'clean' country and '0' refers to a country where business transactions are entirely based on the culture of corruption, involving immense sums of kickbacks, extortion, fraud and embezzlement.

The purpose of this paper is to examine, analyse and report findings, using descriptive informetrics/bibliometrics, on the nature, types and trends of literature on corruption in Africa during the 12-year period from 1990 to 2001 as reflected in key bibliographic databases and database hosts such as EbscoHost, Social Sciences Citation Index and Arts and Humanities Citation Index. It was hypothesised, firstly, that the volume of publications on corruption in a given country does not indicate the extent or level of corruption in that country. Secondly, materials published within the period of study have concentrated on political corruption more than any other form of corruption. Thirdly, many of the articles on corruption in Africa are short and are published in magazines, whereas the long articles are few and are published in journals. Fourthly, there are more single authored articles on corruption in Africa than the co-authored articles. Fifthly, the volume of publications on corruption has steadily increased since 1990. Sixth, journals are the major source of information on corruption in Africa as compared to other publications (e.g. books, government reports, dissertations, etc.) and lastly, the distribution pattern of articles on corruption in Africa in various journals conforms to Bradford's Law of Scattering. The distribution pattern of the authors per the number of papers/articles they have published on corruption in Africa does not statistically conform to Lotka's Law of author productivity.

I. Omwoyo B. Onyancha is Deputy Librarian, University of Eastern Africa, Baraton, Kenya and graduated with a Masters degree in Library and Information Science from the University of Zululand, South Africa in May 2002. 


\section{Literature review}

Historically, corruption is as old as the history of government itself (Chalmers, 1986:22). According to Thompson (2000), the code of Hamurabi, created over 4000 years ago, and the Egyptian law against corrupt practices, are perhaps the earliest anti-corruption measures in evidence. Africa is historically viewed to have been corruption clean until its occupation by foreign invaders, crusaders, settlers and colonialists (Collier, 2000; Mbaku, 1997; and Williams, 1987). Williams (1987:47) asserts that: 'if corruption involves, in part, bribery and buying the co-operation of those in authority, it was employed from the earliest days of colonial expansion to secure the collaboration of traditional rulers'. Similarly, Mbaku (1997) observes that modern corrupt practices were caused by a lack of systematic and proper transition to postcolonial democracies because of lack of time.

There are two broad-based paradigms of corruption, namely relativist and Universalist. The relativist theory argues that what is corrupt in one society may not be so in another, while the Universalist theory claims that there are common properties and characteristics that constitute corruption (Turmex Trading, 200I). This notwithstanding, the causes of corruption are many and varied. They include the following:

- The absence of a strong parliament and lack of transparency in public fund management (Shuabi, 1999; Engelschalk et al., 200I; UN, 1997; jimo et al., 200I)

- A lack of the rule of law, weakness in the role of independent bodies and interference by governmental bodies (Shuabi, 200I)

- Politicisation of key customs positions, sale of jobs, an inefficient civil service, ineffective internal and external audit systems, and a lack of scrutiny from the civil society and the media (Engelschalk et al., 200I)

- Faulty government and development policies, poorly conceived and managed programmes, failing institutions, and a weak criminal justice system (UNDCP, 200I)

- Low salaries and low remuneration to public servants (Ayee, 200I; UNDCP, 200I; jimo et al., 200I)

- Undue or immense power vested on the public service officials (Ayee, 200 I; Jimo et al., 200 I; UN, 1997; Shuabi, 1999)

- Civil wars (Dale, 200I; Warigi, 200I)

- Lack of transparency in privatisation (Warigi, 200I, Dale, 200I; jimo et al., 200I)

Corruption can be categorised into political or administrative (Ayee, 200I), petty or grand (Hall, 1999; Riley, 1999; Quinones, 2000), and individual or systemic (Caiden \& Caiden, 1977). Specifically, corruption takes the form of bribery, extortion, nepotism, influence peddling, fraud and embezzlement (USAID, 200I), among others. Arguably, not everything about corruption is bad, as corruption, in the minds of its proponents, can foster both economic growth and political development (Caiden \& Caiden, 1977; Theobald, 1990; Nye, in Heidenheimer et al., 1997). The negative effects, on the other hand, are numerous and cannot be fully enumerated here in detail. Briefly put, where corruption is practised, capital is channelled to wrong and undesirable areas, entrepreneurs are discouraged, national resources are squandered, administrative capacity is weakened, democracy is undermined and instability is rampant (Theobald, 1990; Hope in Ayee, 200I; Nye, in Heidenheimer et al., 1997). Furthermore, the authors suggest that corruption undermines national integration and promotes instability. The UN (1997) shares these views and adds that corruption frustrates the citizens who, in turn, lose their trust in the government. Corruption also causes the withdrawal of foreign aid from donors.

Smith et a. (2003) associate political corruption with the depletion of forests and the changes in the number of African elephants and black rhinoceroses. In a study carried out to find out whether changes in 'three well surveyed and widespread components of biodiversity' (i.e. forests, African elephants and black rhinoceroses) were related to the levels of corruption, they found strong positive relationships between the governance scores and changes in total forest cover on the one hand, and changes in the numbers of African elephants and black rhinoceroses on the other. The authors argue that political corruption may undermine national efforts towards the conservation of species despite the international community's concern. Finally, the study recommends the international donor community's continued use of its influence to encourage appropriate reforms to offset the effects of poor governance.

Several other measures have been recommended in the fight against corruption, both nationally and internationally. At the national level,

- it requires a combined and collective will of the government (Shuabi, 1999; Ayee, 200 I; Engelschalk et al., 200 I; Collier, 2000; Klitgaard, 1997), a formulation of clear policy frameworks under which every activity is carried out (Engelschalk et al., 200I), and an increase in the risks of punishment of the offenders (Collier, 2000; Ayee, 200I; Klitgaard, 1997; UN, 1997). Other measures consist of establishing and strengthening anti-corruption agencies (Ayee, 200 I; Khan, undated), reforming the rules that govern the activities of individuals and organisations (Mbaku, 1996), and strengthening the judiciary (Shuabi, 1999).

At the international level,

- Klitgaard (1997) suggests regional diagnostic studies, a contest for national anticorruption programmes, and the 
production and dissemination of information materials on corruption, e.g. 'anticorruption tool kits'.

\section{Research methodology}

Informetrics/bibliometric studies are largely categorised into two types, descriptive and evaluative. According to Nicholas \& Ritchie (1978:10), descriptive studies (sometimes called productivity count studies) describe 'the characteristics or features of a literature' while evaluative studies (called behavioural studies or sometimes known as citation studies, though not necessarily restricted to these) 'examine the relationship formed between components of a literature'. The choice of the descriptive method (or a production count method) instead of the evaluative (or citations count technique) to conduct this study has been made with the understanding that these researchers' intention was to maintain consistency and uniformity in analysing the findings from the four online databases chosen for this study. Whereas the ISI databases provide data on the number of citations a particular publication has received, which could have been used to conduct a citations analysis, EBSCOHost databases contained no such information. This meant that it would have been extremely difficult to analyse citations only on publications indexed by ISI databases while ignoring those indexed at EBSCOHost, particularly when ISI databases produced only 85 articles, accounting for $9.7 \%$ of the combined 474 articles from the four databases.

It has also been recognised that productions count has been successfully used in numerous studies (e.g. Ocholla, 2000 \& 200 I; Siddiqui, 1997; Macias-Chapula \& Mijangos-Nolasco, 2002; Amudhavalli \& Krishnamoorthy, 200I; Yitzhaki \& Shahar, 2000; Arunachalam \& Gunasekaran, 200I; Jacobs \& Ingwersen, 2000; Osareh \& Wilson, 200I; Ravi, 200I; Onyancha and Ocholla, 2002) The choice of this method, therefore, is based on the belief that it is the most widely favoured variable in measuring research capacity by individuals, organisations and even countries (Ocholla, 2000) and dertermining the research output of academics through 'publish or perish' indicators(Garfield, 197I).

Corruption literature on Africa between 1990 and $200 \mathrm{I}$ as reflected in four online databases, namely MasterFile Premier (MFP), Academic search Premier (ASP), Social Science Citation Index (SSCl), and Arts and Humanities Citation Index $(\mathrm{A} \& \mathrm{HCl})$ was analysed. A simple Boolean online search was carried out for the 53 independent countries of Africa, alphabetically by country, by combining the name of the country and the subject 'corruption' (truncated as corrupt*). Data was captured and stored in four spreadsheets, which were later merged to form a master spreadsheet. The spreadsheets were constructed in order to allow the capture of data by the variables used to analyse the findings. Data were analysed by the number of authors, number of articles, document type, country, year of publication, nature of corruption, database, source, language, nature of authorship, and size of articles, using both descriptive and inferential statistics. The study used Microsoft Excel to process, present and analyse data.

Besides the four databases used to collect data, the Corruption Perception Index 200I, published by Transparency International, was used to provide the corruption perception scores, which were in turn used to find the relationship between the number of articles and the degree of corruption in each of the African countries. The inclusion of a country in the CPI requires at least three out of a total of 14 surveys conducted by business people, academics and risk analysts. These $\mathrm{CPI}$ scores have been previously used to investigate the relationships between national biodiversity levels and governance (Smith et al., 2003:70).

\section{Findings and discussions}

Publication output by document type, country, database, source and country of origin, length of articles, nature of authorship, as well as the applicability of both Lotka's and Bradford's laws is presented in the findings and discussions.

\subsection{Publications output by document type}

In order to determine the nature of research, the data collected were analysed according to the document types. A total of 509 documents, excluding duplicates, were analysed in this study. These included 474 periodical articles, 34 book reviews, and one letter to the editor. Periodical articles, in this case, included those articles published in magazines, newsletters, and journals. It was observed that out of the 35 document types that are provided for in ISI, only the three mentioned above dealt with corruption in Africa. Periodical articles constituted the largest component (93.1\%), while book reviews and letters to the editors constituted $6.7 \%$ and $0.2 \%$ respectively.

Seemingly, journal and magazine editors have a preference for articles over the other document types, perhaps because they contain current information that is useful for research. However, as both established and new journals have been adding book reviews to their pages, it shows that such reviews are gaining importance as sources of information (Runnels, 1994). Unfortunately, they are always excluded in similar bibliometric studies. The single letter to the editor that was encountered in this study shows that these are not serious sources of information, perhaps because they usually express authors' opinions. 


\subsection{Publications output by country}

Distribution of articles by geographic region is perhaps the most commonly used indicator in descriptive bibliometrics. It is most suited when conducting a comparative study; for example, when comparing research output in two or more countries. A good example is a study that was conducted by Arunachalam \& Gunasekaran (200I) on cardiovascular disease research output in India and China, in which they analysed the findings by country. The distribution of articles by country can also be used in cases where a region has sub-regions. A case in point is a study conducted by Macias-Chapula \& Mijangos-Nolasco (2002), who analysed their findings according to countries in Central Africa in a study on AIDS literature in the region.

The main purpose of distributing articles by country in this study was to determine if there was any correlation between the number of records retrieved per country to the perceived level of corruption in those countries, i.e. to find out whether or not the amount of research on corruption in a particular country can be used to draw conclusions on the level of corruption in that country. This section is therefore intended to answer such questions as: can it, generally and safely, be concluded that the more corrupt a country is, the greater the number of publications produced on that country?

The search yielded the largest number of articles on Nigeria, 96 (20\%) followed by South Africa, 7 I (I5\%) and Kenya 62 (I3\%). A search on some of the countries produced no results. These countries include Burundi, Comoros, Djibouti, Guinea, Mauritania, Mauritius, Reunion, Sao Tome and Principe, Senegal, Sudan, Swaziland, Togo and Tunisia. The results also show that the majority of countries ( 30 or $55.6 \%$ ) yielded fewer than 10 articles each.

Out of the 53 countries analysed in this study, 17 featured in the Corruption Perception Index (CPI). If the ranking provided by Transparency International's CPI is compared with the ranking in this study as shown in Table I, it can be observed that there are only four cases which show that the number of articles can be used to rate a country in terms of its level of corruption. These countries include Nigeria, which is rated as number one in both cases, i.e. the number of articles and the perceived level of corruption.

The illustration also shows that Kenya is the third most corrupt country in Africa, which corresponds to its ranking in this study. Zambia takes position 7 both as ranked in this study and the CPI, while Botswana, which is considered to be the cleanest country in Africa, ranks number 17 in both studies. According to the results of this study, and if the number of articles can be used to measure the level of corruption in a country, Botswana, however, seems not be the cleanest country, since other countries such as Senegal, Tunisia, Mauritius, etc. produced no articles. Yet they are rated to be more corrupt than Botswana.

Table I Number of articles and the perceived level of corruption

\begin{tabular}{|c|c|c|c|c|c|}
\hline Country & Rank in CPI & 200 I CPI Score & Rank in this Study & No. of publications & Official Language \\
\hline Nigeria & 1 & 1 & 1 & 96 & English \\
\hline Uganda & 2 & 1.9 & 6 & 19 & English \\
\hline Kenya & 3 & 2 & 3 & 62 & English \\
\hline Cameroon & 4 & 2 & 13 & 7 & French \\
\hline Tanzania & 5 & 2.2 & 10 & 9 & English \\
\hline Cote d'Ivoire & 6 & 2.4 & 23 & 3 & French \\
\hline Zambia & 7 & 2.6 & 7 & 14 & English \\
\hline Zimbabwe & 8 & 2.9 & 5 & 20 & English \\
\hline Senegal & 9 & 2.9 & 45 & 0 & French \\
\hline Malawi & 10 & 3.2 & 18 & 4 & English \\
\hline Ghana & 11 & 3.4 & 9 & 10 & English \\
\hline Egypt & 12 & 3.6 & 14 & 6 & Arabic \\
\hline Mauritius & 13 & 4.5 & 48 & 0 & English \\
\hline South Africa & 14 & 4.8 & 2 & 71 & English \\
\hline Tunisia & 15 & 5.3 & 41 & 0 & Arabic \\
\hline Namibia & 16 & 5.4 & 33 & I & English \\
\hline Botswana & 17 & 6 & 17 & 5 & English \\
\hline
\end{tabular}


Furthermore, the following scatter diagram reveals that there is an inverse relationship between the number of articles produced on a given country and that country's CPI score.

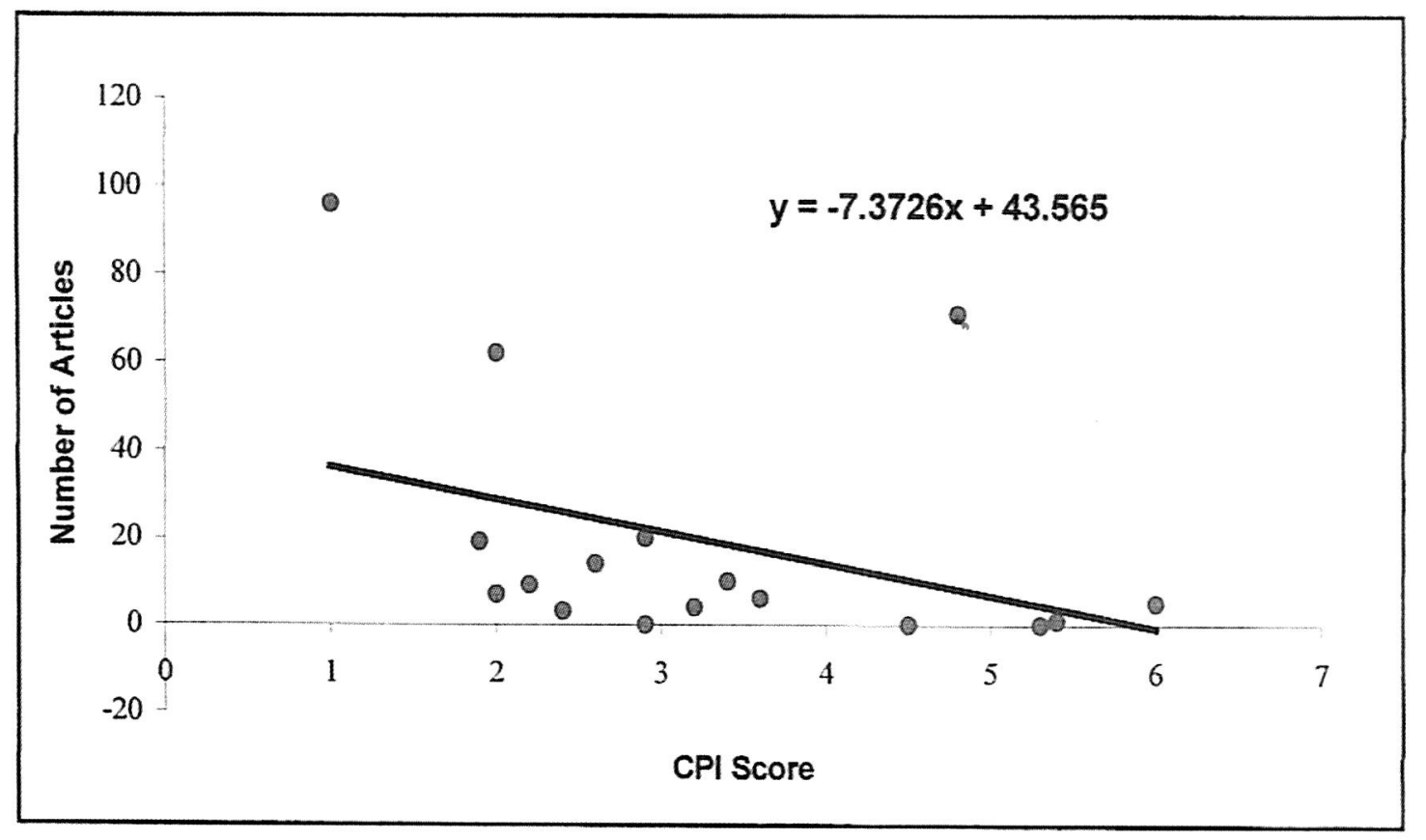

Figure 1. Corruption literature on Africa: correlation between the number of articles and the CPI scores.

To test the correlation, a Pearson Correlation test was conducted using a Systat 10 statistical package. The test was conducted between the number of articles and the CPI score (this score indicates the perceived level of corruption in a country). The test produced a correlation value of -0.370 , indicating that the two variables are negatively related. This means that the number of articles is less in those countries whose $\mathrm{CPI}$ scores are high, i.e. the countries whose perceived level of corruption is low. That is, the smaller the number of articles, the lower the level of corruption. It was, however, found that the 0.37 correlation value was not significant at $95 \%$ probability with $16 \mathrm{df}$ (degree of freedom). It is, therefore, not sufficient to conclude that the number of articles and the level of corruption are related.

Although the number of articles alone cannot, therefore, be an obvious indication of the level of corruption in a country, it can be seen from the above two illustrations that there is some relationship between the two. It can be observed that the majority of the countries which produced records on corruption are English-speaking, and perhaps that is why some countries, especially the French-speaking, produced no articles at all. This means, therefore, that if research was conducted to incorporate the French and other languages, the relationship between the number of publications and the level of corruption in a given country may be stronger than is illustrated above.

\subsection{Trend of publications output by year}

One other variable that is commonly used in publications count is the measurement of publications growth. This is perhaps because such growth over a given period of time can be used to measure the growth of knowledge (Sengupta, 1992; Tague et al., 1981). Figure 2 below identifies the publications trends of corruption literature from 1990-200I.

The number of articles has risen markedly, from 9 in 1990 to 58 in 2001, which gives a significant percentage growth of $71.6 \%$. This, however, does not mean that 58 was the peak. As the graph shows, the largest number of articles was witnessed in 1999, namely 78. There was a slight decline from 21 to 16 articles between 1991 and 1992. The number of articles decreased by $9 \%$ between 1999 and 2000 , while there was a further dramatic decline to 13 (I8\%) between 2000 and 2001 .

The increase of publications on corruption in the African countries can be attributed to democratisation, the media and press reforms, international pressure, the international community's commissioning of research in developing countries, and the publishing of the Corruption Perceptions Index by TI. The past decade has also witnessed a decline in the number of publications in three stages. It is likely that this was caused by diversion of attention to other pressing issues, such as poverty and Aids, and the involvement of the vocal politicians cum authors in corrupt practices. 


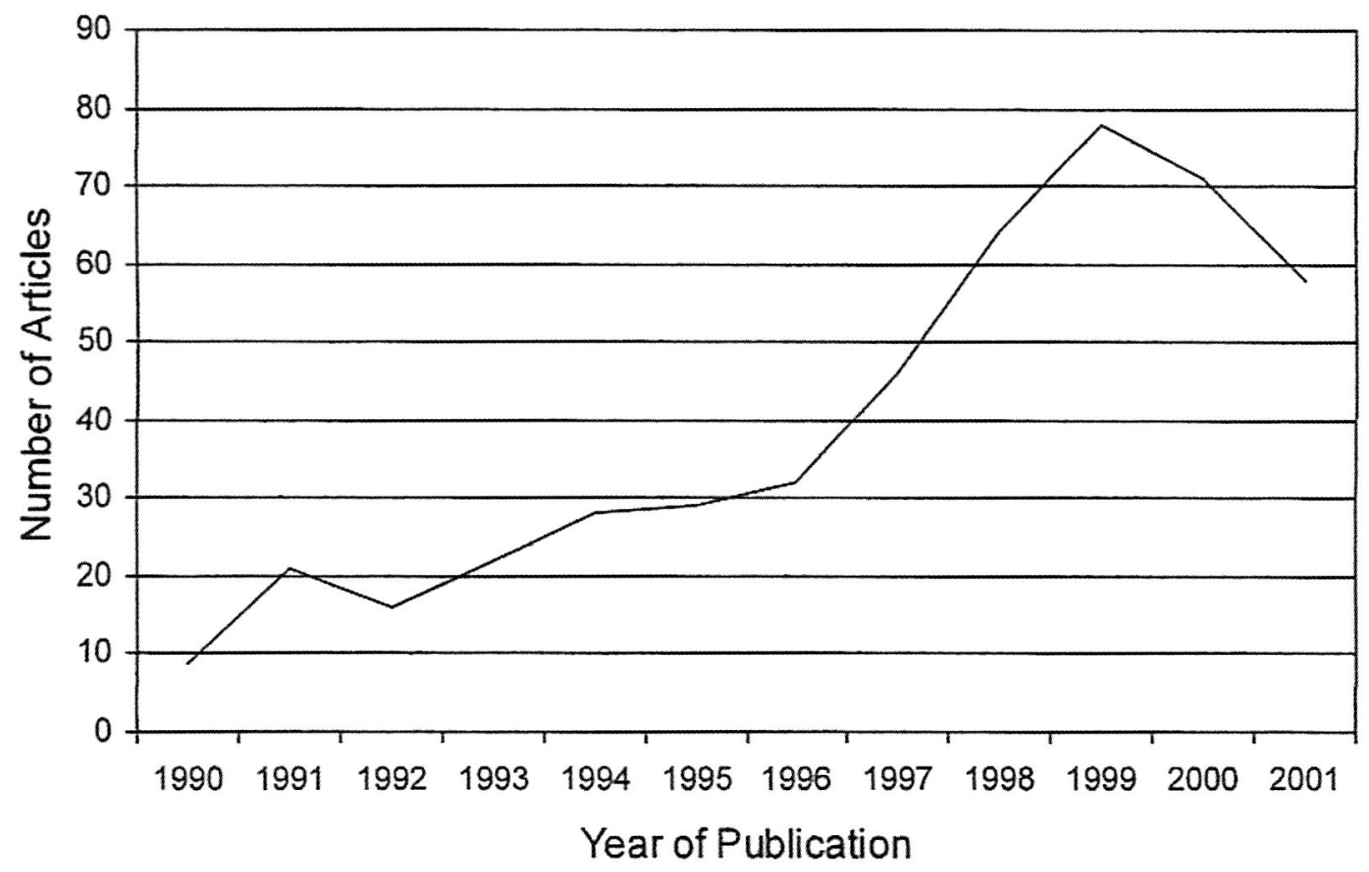

Figure 2. Corruption literature on Africa: trend of publications output between 1990 and 2001

\subsection{Publications output by the nature of corruption}

Of the 474 articles analysed, $323(68.1 \%)$ were on political corruption and 87 (18.4\%) on administrative corruption. There were, however, 64 (13.5\%) articles whose content analysis by subject could not reveal the category to which they belonged. These articles were then classified as dealing with both administrative and political corruption. Political corruption was, therefore, the most researched form of corruption. Seemingly, both the international and national communities believe that by reducing or curbing political corruption, they would be able to combat administrative corruption. Hence, much attention is given to political corruption and more articles are published on it.

\subsection{Publications output by database}

Figure 3 shows the number of documents in each of the four databases used in this study and how these databases shared the documents. The results show that out of a total number of 880 documents retrieved, MFP, hosted by EBSCOHost, produced the largest number of documents (409 or $46.5 \%$ ), while the ASP, also hosted by EBSCOHost, yielded 386 (43.8\%). The A\&HCl and SSCI, both hosted by ISI, produced $4(0.5 \%)$ and $8 \mathrm{I}(9.2 \%)$ respectively. When analysed by database host, EBSCOHost indexed 795 (90.3\%) while ISI indexed 85 (9.7\%) documents. EBSCO publishing company produced more publications on corruption, mainly because it indexes both magazines and journals whose inclusion in the company's products depends on the subscriber volume (Kummerer, 1992) while the ISI indexes only high impact journals (Testa, 2002). In addition, it can also be seen that $\mathrm{A} \& \mathrm{HCl}$ produced the least number of documents on corruption, which can be attributed to the fact that corruption, or its broader or related terms, is not among the indexed disciplines in $\mathrm{A} \& \mathrm{HCl}$.

\subsection{Publications output by source and country of origin}

The majority of these sources were journals ( 73 or $57.9 \%$ ) followed by magazines/newsletters ( 50 or $39.7 \%$ ) and bookreviewing serials ( 3 or $2.4 \%$ ). Journals are therefore the most frequently used form of publication for articles on corruption in Africa, although in reality grey literature, and more especially newspapers and magazines, usually reports more corrupt cases. Behrens et al. (1999) observe that magazines are periodicals of less serious nature while journals are periodicals of a scholarly nature. Arguably, this could explain why ISI and other database hosts do not place much emphasis on magazines and instead prefer to index only journals.

An analysis of the sources by country of origin reveals that of the total of 73 journals, $40(54.8 \%)$ were published in the United States, 27 (37\%) in the United Kingdom and 3 (4.1\%) in the Netherlands. Canada, France and South Africa were each responsible for I (I.4\%). Interestingly, only one journal originated from Africa. Table 2 shows that no journals originated from Australia. The United States once again produced the most magazines (35 or $70 \%$ ) and the United Kingdom produced 10 (20\%). 


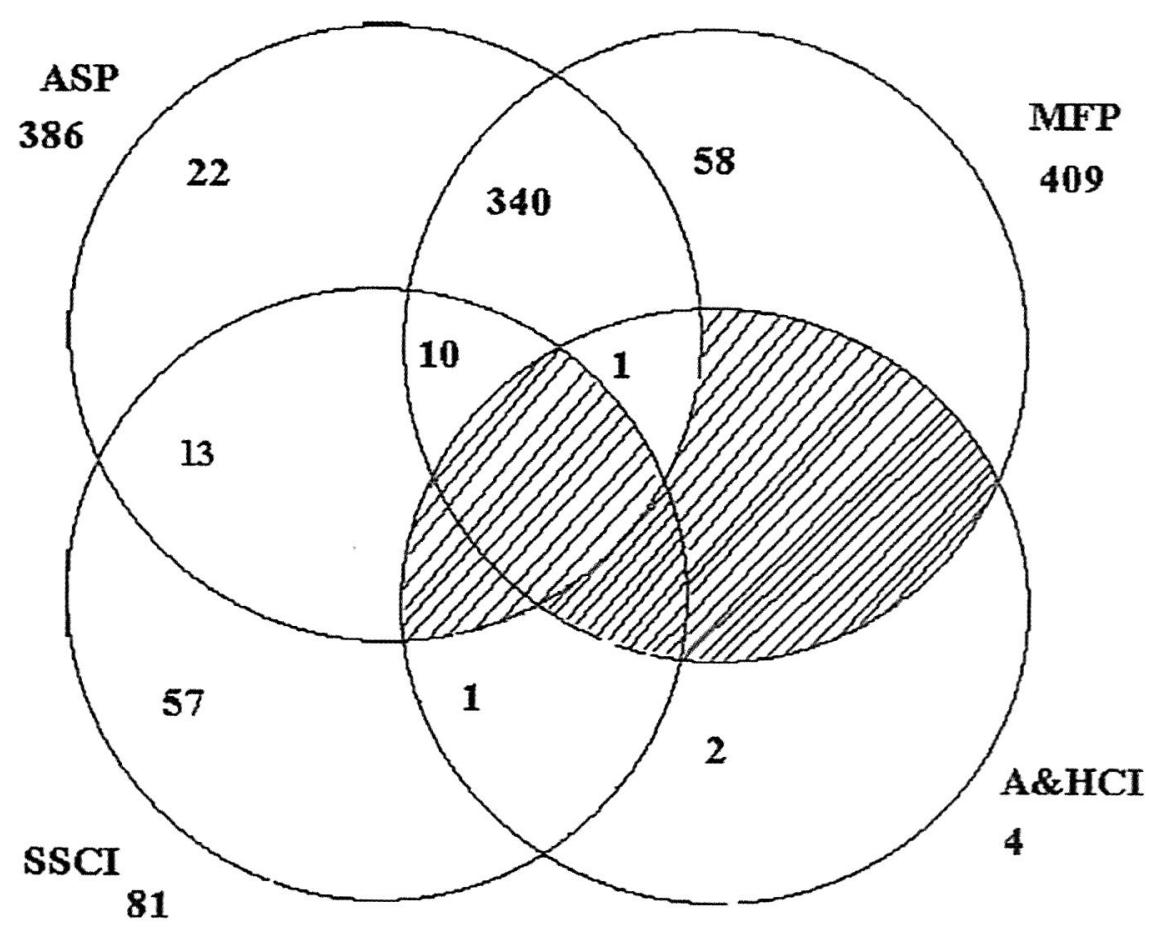

Figure 3. Corruption literature on Africa: distribution by database

Other countries that contributed to the publication of magazines/newsletters include Canada (8\%), France (2\%) and Australia (2\%). Of the three book-reviewing serials, two originated from the United States while the United Kingdom produced only one. This suggests, therefore, that the majority of the periodicals abstracted and indexed in both the ISI and EBSCO are actually published in these two countries. The selection policies of these two companies perhaps explain why this is so. Seemingly, both the highly cited journals and those with a high subscriber volume are published in the United Kingdom or the United States.

Table 2. Corruption literature on Africa: distribution by source and country of Origin $(N=126)$

\begin{tabular}{lllll}
\hline Country & Journals & Magazines/Newsletters & Book Reviews & Total \\
\hline United States & 40 & 35 & 2 & 77 \\
United Kingdom & 27 & 10 & 1 & 28 \\
Canada & 1 & 4 & 0 & 5 \\
Netherlands & 3 & 0 & 0 & 3 \\
France & 1 & 1 & 0 & 2 \\
South Africa & 1 & 0 & 0 & 1 \\
Australia & 0 & 1 & 0 & 1 \\
\hline Total & 73 & 50 & 3 & 126 \\
\hline
\end{tabular}

Content analysis by subject showed that the subject fields in which articles on corruption were published included history, anthropology, ethnic and multicultural studies, economics and business, management, sociology and social work and even library and information science. This shows that the subject of corruption affects all spheres of life and is not restricted to political science alone. Authors in other fields of knowledge are as concerned about corruption as are the political scientists. That is to say, corruption is everyone's concern.

\subsection{Publications output by length of articles}

The main purpose of conducting an evaluation of the length of the documents was to find out whether lengthy articles are preferred by authors to the short articles. In other words, which of the two is more common in corruption literature? Previously, studies have been conducted to evaluate the size of documents with the aim of testing the "hypothesis that a 
paper with more pages will have more "significant" words in its title' (Yitzhaki (2000:759) and to find out the influence the number of authors have on the length of articles (Steynberg \& Rossouw, 1995).

The length of each article is reflected by the number of words it contains. Only the EBSCOHost databases, i.e. ASP and MFP, provided the sizes of the articles. Table 3 shows that there were a total of 270 articles whose sizes were provided in the form of a word count. This accounts for $57 \%$ of the total number of articles analysed in this study. On average, each article consisted of about 533 words. This figure, although it is the mean, also indicates in which class interval the majority of the articles are located. Most articles ( 112 or $41.5 \%$ of the total number of articles) were found to be located in the 50I-1000 class interval. This is the same location as for the average number of words per article. Another observation was that the majority of articles were short, with a maximum of 1000 words. Actually, they form a cumulative percentage of $64.8 \%$ of the total number of articles analysed, and are between one and three pages long.

Several reasons could be given to explain why most authors publish short rather than long articles. One reason could be the periodical publishing company's policy as regards the length of the articles to be submitted by the authors. Policies concerning the size of articles in journals differ greatly from those of magazines. For instance, perhaps due to the limited space, writers are advised to submit short articles to magazine publishing companies. A quick look at the articles in the range of $\mathrm{I}-1000$ words revealed that approximately $85 \%$ of them were published in magazines/newsletters, which could explain why such a large number of articles were short.

Secondly, it was found that almost all the magazines and a few of the journals were not peer-reviewed, which may affect consistency in publishing. Thirdly, as Steynberg \& Rossouw (1995) observe in their study of multiple authorship in biomedical papers in South Africa, there has been a trend in which authors tend to publish short articles, a fact that the authors attribute to the pressure to publish as many papers as possible and to the typographical factors, e.g. the printing economy. They also argue that 'the number of authors does not seem to have any influence on the length of an article' and that 'long articles occur more frequently where there are five or fewer authors' (Steynberg \& Rossouw, 1995:47I).

Table 3 Corruption literature on Africa: distribution by size

\begin{tabular}{|c|c|c|c|c|c|}
\hline \multicolumn{6}{|l|}{$N=270$} \\
\hline Number of Words in Text $(x)$ & Midpoint of $x\left(x_{1}\right)$ & $f$ & $\mathrm{fx}_{1}$ & cf & Percentage \\
\hline$|150|-12000$ & 11750 & 1 & 11750 & 270 & 0.4 \\
\hline $1100|-1| 500$ & 11250 & 1 & 11250 & 269 & 0.4 \\
\hline $10501-11000$ & 10750 & 2 & 21500 & 268 & 0.7 \\
\hline $10001-10500$ & 10250 & 2 & 20500 & 266 & 0.7 \\
\hline $9501-10000$ & 9750 & 2 & 19500 & 264 & 0.7 \\
\hline $9001-9500$ & 9250 & 2 & 18500 & 262 & 0.7 \\
\hline $8501-9000$ & 8750 & 1 & 8750 & 260 & 0.4 \\
\hline $800 I-8500$ & 8250 & 2 & 16500 & 259 & 0.7 \\
\hline $750 I-8000$ & 7750 & 2 & 15500 & 257 & 0.7 \\
\hline $700 I-7500$ & 7250 & 0 & 0 & 255 & 0 \\
\hline $6501-7000$ & 6750 & 2 & 13500 & 255 & 0.7 \\
\hline $600 I-6500$ & 6250 & 0 & 0 & 253 & 0 \\
\hline $550 I-6000$ & 5750 & I & 5750 & 253 & 0.4 \\
\hline $500 \mathrm{I}-5500$ & 5250 & 1 & 5250 & 252 & 0.4 \\
\hline $450 \mathrm{I}-5000$ & 4750 & 1 & 4750 & 251 & 0.4 \\
\hline $400 I-4500$ & 4250 & 0 & 0 & 250 & 0 \\
\hline $350 I-4000$ & 3750 & 3 & 11250 & 250 & 1.1 \\
\hline $3001-3500$ & 3250 & 3 & 9750 & 247 & 1.1 \\
\hline $2501-3000$ & 2750 & 7 & 19250 & 244 & 2.6 \\
\hline $2001-2500$ & 2250 & 7 & 15750 & 237 & 2.6 \\
\hline$|50|-2000$ & 1750 & 18 & 31250 & 230 & 6.7 \\
\hline $1001-1500$ & 1250 & 37 & 46250 & 212 & 13.7 \\
\hline $501-1000$ & 750 & 112 & 84000 & 175 & 41.5 \\
\hline $1-500$ & 250 & 63 & 15750 & 63 & 23.3 \\
\hline
\end{tabular}


Finally, elaborate scientific methods of publishing may have not been followed by all authors when writing their papers and requirements in this regard may differ from one journal to another. For instance, certain journals may require that all the components of the research paper (i.e. abstract, introduction, methodology, literature review, objectives, findings, discussion, conclusion, references, etc.) are to be included, while others may not be so keen on certain aspects. It is therefore possible that short articles did not contain all the above.

One question that kept cropping up in our discussion is whether long articles are superior in quality to short articles. Interestingly, this was found to be true to some extent. In the first instance, $85 \%$ of the articles that were I 000 words or less were published in magazines, which Behrens et al. (1999) label as periodicals of less serious nature. Articles in magazines usually do not require serious research, nor do they have to meet elaborate scientific requirements for publishing. This may be construed to mean that they are inferior in quality to long articles, which were found to be published more often in journals. However, this argument does not hold true when comparing two articles published in either magazines or journals. A short journal article may be of a higher quality than a lengthy one, depending on the subject area, the author's skills in summarising the findings and the journal's policy, which may require that authors submit articles of specific lengths. Arguably, Orr \& Leeds (as cited in Steynberg \& Rossouw, 1995:470) conclude that the length of articles is, at its best, a quantitative indicator and cannot be equated with quality of content.

\subsection{Publications output by nature of authorship}

Single authorship was found to be leading, with 94 articles published in journals and 199 articles in magazines/newsletters, as shown in Table 4. There were 19 co-authored articles in journals and 30 in magazines/newsletters.

Single-authored articles therefore featured more often than co-authored papers in both cases. While this is understandable in the case of magazines, where the majority of the articles are single-authored, it is not clear why there are more single-authored than co-authored articles in journals. It could be that research on corruption, unlike research in areas such as nuclear science, for example, does not require much collaboration. Secondly, the academic environment in Africa is not conducive to collaboration. A study carried out by Cunningham (200I:144) found that authors tend to collaborate with members of the same department, research laboratory, commercial unit or institution. Hence, it can be argued that many academics in African institutions would have preferred to conduct joint research; this may not be done because there could be few colleagues within the same department or university who share the same interest, or are fairly active in research. Lastly, the predominance of single-authored articles could be due to the researchers' individualistic interests. For example, many are researchers who may be writing for academic promotions.

Table 4 Corruption literature on Africa: distribution by nature of authorship and source $(N=474)$

\begin{tabular}{|c|c|c|c|c|c|c|}
\hline \multirow[t]{2}{*}{ Nature of authorship } & \multicolumn{2}{|l|}{ Journals } & \multicolumn{2}{|c|}{ Magazines/Newsletters } & \multicolumn{2}{|l|}{ Total } \\
\hline & Articles & $\%$ & Articles & $\%$ & Articles & $\%$ \\
\hline Single Authorship & 94 & 76.4 & 199 & 56.7 & 293 & 61.8 \\
\hline Co-Authorship & 19 & 15.5 & 30 & 8.5 & 49 & 10.3 \\
\hline Corporate Authorship & 8 & 6.5 & 109 & 31.1 & 117 & 24.7 \\
\hline Others & 2 & 1.6 & 13 & 3.7 & 15 & 3.2 \\
\hline Total & 123 & 100 & 351 & 100 & 474 & 100 \\
\hline
\end{tabular}

Research has shown, however, that single-authored articles are on the decline while co-authored articles have shown an increasing trend, especially in pure and applied sciences (Ravi, 200I:582; Hartinah, 2001:227). Cunningham (200I) too found that out of 234, only 38 (approximately 16\%) were single-authored. Garg (2001:173) concurs with both Ravi and Cunningham that modern research and development is a collective activity and generally conducted by a group rather than a single individual'. Cunningham (200I) attributes the high number of co-authored papers to the emphasis funding agencies place on institution-based research projects in the United States. An examination of the above mentioned studies revealed that all of them are based on scientific research. Could it be true that the rate of collaboration in authorship is higher in pure and applied sciences than in the humanities and social sciences?

\subsection{Applicability of Lotka's Law of Author Productivity}

When omitting those articles with corporate authorship or whose statement of responsibility was not clear, this study found that there were a total of 94 authors who contributed at least one article each. Of these, $84(89.4 \%)$ contributed one paper each on corruption in Africa while four (4.3\%) published two articles each. It was also found that single authors contributed three to seven papers, as shown in Table 5, whereas none published six papers. 
By plotting this observation on a table and comparing it with the expected outcome using Lotka's law, it can be observed that despite the fact that there was 'a substantial number of authors who have each contributed one publication' (Wallace, 1989:10), as stipulated in Lotka's Law, the $89.6 \%$ (or 0.89 ) is more than the $60 \%$ (or 0.60 ) proposed by Lotka. Table 5 further demonstrates that instead of 56 (i.e. $60 \%$ of 94 ) authors contributing one article each according to Lotka's Law, there were 84 authors who published one article each according to this study. It also shows that there were only four two-paper contributions made instead of 14 , one three-paper contribution instead of six and so on.

Table 5. Application of Lotka's Law to Corruption Literature ( $N=94)$

\begin{tabular}{llll}
\hline Findings according to this study & \multicolumn{2}{l}{ Expected results according to Lotka's Law } \\
\hline N contributions & Authors making n contributions & N contributions & Authors making n contributions \\
\hline I & 84 & 1 & 56 \\
2 & 4 & 2 & 14 \\
3 & 1 & 3 & 6 \\
4 & 1 & 4 & 4 \\
5 & 1 & 5 & 2 \\
7 & 0 & 6 & 1 \\
\hline
\end{tabular}

4.10 Applicability of Bradford's Law of Scattering

Table 6 shows the distribution of articles in journals. Zone one, which is referred to as Bradford's nucleus or core, comprises the first five journals, which produced $4 \mathrm{I}$ articles. The $4 \mathrm{I}$ articles form one third of the total number of articles. Zone two comprises the next 12 journals containing a total of 37 articles, while the third zone consists of 45 articles published in the 45 journals.

Table 6. Bradford's Law of Distribution of Articles $(\mathrm{N}=123)$

\begin{tabular}{lllll}
\hline Zone & Journals & \multicolumn{3}{c}{ Articles } \\
\hline & Number of Journals & $\%$ & Number of Articles & $\%$ \\
\hline 1 & 5 & 8.0 & 41 & 33.3 \\
2 & 12 & 19.4 & 37 & 30.1 \\
3 & 45 & 72.6 & 45 & 36.6 \\
\hline Total & 62 & 100 & 123 & 100 \\
\hline
\end{tabular}

This approach was taken so that the first zone will contain 6-10 articles (i.e. above 5), while zone two would comprise journals that published over one article each. It can be seen that the total number of articles in the three zones is in the proportion of 5:12:45, which is roughly equivalent to $1: 3: 9$. This proportion is in, turn, relatively the same as $3^{0}: 3^{1}: 3^{2}$. Taking 3 as the $n$, which is referred to as the Bradford's multiplier in Bradford's law, and taking Diodato's (1994:26) approach to testing Bradford's law, the above proportion will resemble Bradford's I:n: $n^{2} \ldots$ or $n^{0}: n^{1}: n^{2}$.

\section{Conclusions and recommendations}

Twining (200I, Uses section, para. 4) summarises the use of bibliometrics as a 'decision-support methodology used by LIS and KM [Knowledge Management] professionals in and across virtually every discipline, including computer science, telecommunication, political science, agriculture, biology, neuroscience, education, mathematics, business, industry, religion, and art'. Indeed, it has been shown in this study's literature review and findings that bibliometrics is not limited in its usage to a specific subject area. This method has been used in the present study to explore and assess the nature, types and trends of literature on corruption in Africa between 1990 and 200I, as reflected in four online bibliographic databases.

Based on the findings of this study, we conclude the following:

- Periodicals, in general, are the major source of publications on corruption in Africa.

- Although the number of publications on corruption in a given country cannot exclusively be used to determine the

SA Jnl Libs \& Info Sci 2004, 70(2) 
level of corruption in that country, it can be said that if all conditions remain constant (i.e. language, freedom of expression, etc.), there could be a positive relationship between the number of publications and the perceived level of corruption.

- Research on corruption in Africa, though it is ongoing, is published in foreign periodicals in the form of articles (or papers) as opposed to books, government reports, theses, and dissertations.

- Political corruption has attracted the majority of the authors, as opposed to administrative corruption, which was the least researched form of corruption.

- Although all databases under the scope of this study yielded documents on corruption, the most suitable databases for conducting research on corruption in Africa are the Academic Search Premier and the MasterFile Premier hosted by EBSCO.

- The majority of authors prefer to publish short articles, which range up to I 000 words, i.e. I-3 pages.

- Single authorship of publications is common in the subject area of corruption and forms the highest proportion of author productivity.

- In line with Bradford's observation, this study shows that a few journals published a relatively high percentage of articles on corruption, while many published one article each.

- Although the majority of authors published one article each, a small number of authors published a few articles each, and a much smaller number of authors were found to be prolific, Lotka's Law does not statistically apply to corruption literature.

- Authors from developing countries do not publish in highly cited journals, and as such their papers are not indexed in the online database publishing companies, especially in the case of ISI.

In order to improve research on corruption and in view of the findings of this study, we recommend the following:

- There is a need for African journals to improve their quality so as to have international recognition, which, in turn, will attract renowned authors by, for instance, changing the editorial policy and revising the authors' royalties with an intention of increasing the same.

- Authors should be encouraged to publish in high-impact journals that are indexed by major database publishing companies such as ISI, through offering incentives. However, this should also be accompanied by subscription of journals, both privately and by institution.

- In order for African journals to 'compete successfully with journals published elsewhere, they need to offer access to full text online' (Rosenberg, 2002, Summary section, para. I). This, in turn, will make them available to a larger audience and hence have a wider readership.

- Major database publishers, such as ISI, need to offer special and lower subscription rates to institutions in developing countries.

- Database publishers should provide full bibliographic details of articles and brief biographical information on the authors of those articles indexed in their databases.

- Governments and non-governmental organisations concerned with the fight against corruption should encourage and sponsor research on corruption in Africa by, for instance, commissioning research in the discipline.

- The database publishing companies' indexing and selection policies are published online for easy access by researchers. This is because situations usually arise in which a researcher needs to discuss his or her findings in respect to the indexing and selection policies.

- The use of informetric indicators for determining the corruption index of countries, institutions or individuals should be further explored.

- Since the majority of corruption literature on Africa is published in non-journal publications, some of which are quite authoritative, such as The Times, Economist, Newsweek, Christian Science Monitor, New African and Africa Report, these records should explored by using an informetric approach. As Lewison (2001:185) recommends, bibliometricians need to make use of newspapers in conducting bibliometric studies because they are cheap and readily available and normally change little between editions; they are widely read and their readership is well characterised both socially and geographically; the citing articles have many of the characteristics of a scientific paper, e.g. author, title, and length of paper; and the cited sources are usually identified reasonably clearly.

\section{References}

Amudhavalli, A. \& Krishnamoorthy, G. 200I. Medical research and development output in India. In: Davis, M. \& Wilson, C. S., (Eds.). Proceedings of the 8th International Conference on Scientometrics and Informetrics, 16-20 July 200 I. Sydney: Bibliometric and Informetric Research Group, UNSW, 31-39.

Arunachalam, S. \& Gunasekaran, S. 200I. Cardiovascular diseases research in India and China in the 1990s. In: Davis, M. \& Wilson, C. S., (Eds.). Proceedings of the 8th International Conference on Scientometrics and Informetrics, 16-20 July 2001. Sydney: Bibliometric and Informetric Research Group, UNSW, 53-62.

Ayee, J.R.A. 200I. Corruption and the future of the public service in Africa. Paper delivered at the 13 th Congress of the African Association of Political Science, Yaounde, Cameroon, 19-22 June. [Online]. http://www.aaps.co.zw/Publications/AlJP/Ayee.html Accessed $5^{\text {th }}$ March 2002. 
Behrens, S.J., Olen, S.I.I., \& Machet, M.P. 1999. Mastering information skills. Pretoria: Unisa Press.

Caiden, G.E. \& Caiden, N.J. 1977. Administrative corruption. Public Administrative Review, 37:30I. [Online] Available at EBSCOHost database: http://search.global.epnet.com/ Accessed 6 ${ }^{\text {th }}$ February 2002.

Chalmers, D.M. 1986. Political corruption. The Encyclopaedia Americana, international edition. Danbury, CT: Grolier Inc., 2223.

Collier, P. 2000. How to reduce corruption. African Development Review, 12(2):191-205. [Online]. Available at EBSCOHost Database: http://search.global.epnet.com/ Accessed on 14 ${ }^{\text {th }}$ February 2002.

Cunningham, S. 200I. The birth of a field: an analysis of the 1994-2000 ACM Digital Libraries Conferences. In: Davis, M. \& Wilson, C. S., (Eds.). Proceedings of the 8th International Conference on Scientometrics and Informetrics, I6-20 July $200 \mathrm{I}$. Sydney: Bibliometric and Informetric Research Group, UNSW, I39-I46.

Dale, P. 200I. Southern Africa. In: Hodess, R., Banfield, J., \& Wolfe, T., (Eds.). Global corruption report. Berlin, Transparency International, 81-94. http://www.globalcorruptionreport.org/download/rr_wwc_africa.pdf Accessed on I $2^{\text {th }}$ March 2002.

Diodato, V. 1994. Dictionary of Bibliometrics. New York: Haworth.

Engelschalk, M., Hansson, A., \& Sutch H. 200I. World Bank Approaches to Anti-Corruption in Customs. [Online]. http:// Inweb/8.worldbank.org/twu/gfp.nsf/files/ customs.pdf/\$FILE/customs.pdf Accessed on 6 ${ }^{\text {th }}$ February 2002.

Garfield, E. 197I. Publication counting vs citation counting in evaluating research [electronic version]. Essays of an Information Scientist, I:179-181.

Garg, K. C. 200I. Scientometrics of laser research in India and China. In: Davis, M. \& Wilson, C. S., (Eds.). Proceedings of the 8th International Conference on Scientometrics and Informetrics, 16-20 July 200I. Sydney: Bibliometric and Informetric Research Group, UNSW, I67-I77.

Hall, D. 1999. Privatisation, multinationals, and corruption. Development in Practice, 9(5): 539. Available at EBSCOHost database: http://search.global.epnet.com/ Accessed 12 ${ }^{\text {th }}$ March 2002.

Hartinah, S., Davis, M., Hydari, A. \& Kent, P. 200I. Indonesian nutrition research papers 1979-98: a bibliometric analysis. In: Davis, M. \& Wilson, C. S., (Eds.). Proceedings of the 8th International Conference on Scientometrics and Informetrics, 16-20 July 200 I. Sydney: Bibliometric and Informetric Research Group, UNSW, 225-I77.

Heidenheimer, A.J., Johnson, M., \& LeVine, V.T., (Eds.). 1997. Political corruption: a handbook. London: Transaction.

Jacobs, D. \& Ingwersen, P. 2000. A bibliometric study of the publication patterns in the sciences of South African scholars, I98I96. Scientometrics, 47(I):75-93

Jimo, H., Sy, T., \& Wade, D. 200I. West and West-Central Africa. In: Hodess, R., Banfield, J., \& Wolfe, T., (Eds.). Global corruption report. Berlin, Transparency International, 8I-94. http://www.globalcorruptionreport.org/download/rr_wwc_africa.pdf Accessed on 12 $2^{\text {th }}$ March 2002.

Khan, M. M. (undated). Political and administrative corruption: concepts, comparative experiences and Bangladesh case. Paper prepared for Transparency International - Bangladesh Chapter. [Online]. http://ti-bangladesh.org/docs/reseach/Mkhan.htm Accessed on 12 ${ }^{\text {th }}$ March 2002.

Klitgaard, R. 1997. International cooperation against corruption. http://gwdg.de/ uwvw/ Research_area/klitgaard.htm Accessed $27^{\text {th }}$ February 2002.

Kummerer, M. 1992. Indexing and database selection at EBSCO. Serials Review, 18(3). [Online]. Available at EBSCO Website: http://search.epnet.global.com Accessed 25th June 2002.

Lewison, G. 200I. From biomedical research to health improvement. Scientometrics, 54(2): 179- 192.

Macias-Chapula, C.A. \& Mijangos-Nolasco, A. 2002. Bibliometric analysis of Aids literature in Central Africa. Scientometrics, 54(2):309-317.

Mbaku, J.M. 1996. Bureaucratic corruption in Africa: the futility of cleanups. CATO Journal, I6(I). [Online]. Available at EBSCOHost database: http://search.global.epnet.com/ Accessed February 2 I $^{\text {st }}, 2002$

Mbaku, J.M. 1997. Institutions and reform in Africa: the public choice perspective. Wesport, CT: Praeger.

Nicholas, D. \& Ritchie, M. 1978. Literature and bibliometrics. London: Clive Bingley.

Ocholla, D.N. 2000. Research capacity in library and information science in South Africa - an overview. Proceedings of the $66^{\text {th }}$ IFLA Council and General Conference, Jerusalem, Israel, 13-18 August 2000. [Online]. http://www.ifla.org/IV/ifla66/papers/ 054-I27e.htm Accessed $4^{\text {th }}$ April 2002.

Ocholla, Dennis N. 200I. An Informetric Study of the Publication Pattern in Library and Information Science in South Africa: 1993 -200I.In Davis, M., and Wilson, C.S. (eds.), Proceedings of the 8th International Conference on Scientometrics and Informetrics, 16-20 July 200I. Sydney: Bibliometric and Informetric Research Group, UNSW,86I-863

Onyancha, O.B., \& Ocholla, D.N. 2002. An informetric analysis of the corruption literature based on Africa between 1990 and 200I. In Bothma, T., \& Kaniki(eds.), A. progress in Library and Information Science in Southern Africa. Proceedings of the second biennial DISSAnet Conference.pp. 105-124 (available online: http://www.Dissanet.com Accessed on I8 ${ }^{\text {th }}$ July 2003)

Osareh, F. \& Wilson, C. S. 200I. Iranian scientific publications: collaboration, growth, and development from 1985-I999. In: Davis, M. \& Wilson, C. S., (Eds.). Proceedings of the 8th International Conference on Scientometrics and Informetrics, $16-20$ July 200I. Sydney: Bibliometric and Informetric Research Group, UNSW, 499-509.

Quinones, E. 2000. OECD Observer: What is Corruption? [Online] http://oecdobserver.org/news/fullstory.php/aid/233/ what is corruption.html Accessed $27^{\text {th }}$ February $27^{\text {th }} 2002$.

Ravi, S. $\overline{2} 0 \overline{0}$ I. Growth and collaborative trends in nuclear science research literature: a case of India, 1980-1994. In: Davis, M. \& Wilson, C. S., (Eds.). Proceedings of the 8th International Conference on Scientometrics and Informetrics, 16-20 July 2001. Sydney: Bibliometric and Informetric Research Group, UNSW, 573-585.

Riley, S.P. 1999. Petty corruption and development. Development in Practice, 9(I\&2). EBSCOHost database Website: http:// search.global.epnet.com/ Accessed 12 ${ }^{\text {th }}$ March 2002.

Rosenberg, D. 2002. African Journals OnLine Publishing Project (AJOPP). [Online]. http://www.inasp.org.uk/psi/ajopp/ Accessed $7^{\text {th }}$ August 2002.

SA Jnl Libs \& Info Sci 2004, 70(2) 
Runnels, C. 1994. The place of book reviews in the professional literature. Journal of Field Archaeology, 21:357-360. [Online]. http://jfa-www.bu.edu/Articles/RunnelsC_2I_3.html Accessed I $2^{\text {th }}$ June 2002

Sengupta, I.N. 1992. Bibliometrics, informetrics, scientometrics and librametrics: an overview. Libri, 42(2):75-98.

Shuabi, A. 1999. Elements of corruption in the Middle East and North Africa: the Palestinian case. Paper presented at the 9th International Anti-Corruption Conference, Durban, South Africa, 9-15 October 1999. [Online]. http://www.transparency.org/ iacc/9th_iacc/papers/dayl/ws5/dlws5_ashuaibi.html Accessed 6 ${ }^{\text {th }}$ February 2002.

Siddiqui, M.A. 1997. A bibliometric study of authorship characteristics in four international information science journals. International Forum on Information and Documentation, 22(3):3-10.

Smith, R.J., Muir, R.D.J., Walpole, M.J., Balmford, A., \& Leader-Williams, N. 2003. Governance and the loss of biodiversity. Nature, 426:67-70.

Steynberg, S. \& Rossouw, S. F. (1995). Multiple authorship in biomedical papers: a South African case study. Journal of the American Society for Information Science, 46 (6), 468-472.

Tague, J., Beheshti, J. \& Rees-Potter, L. 198I. The law of exponential growth: evidence, implementation and forecasts. Library Trends, 30:125-149.

Testa, J. 2002. The ISI database: the journal selection process. [Online]. http://www.isinet.com/isi/ hot/ essa...nofmaterialforcoverage/ $199701 . \mathrm{html}$ Accessed $5^{\text {th }}$ May 2002.

Theobald, R. 1990. Corruption, development and underdevelopment. London: Macmillan Press.

Thompson, D.J. 2000. The history of corruption. [Online]. http://www.ecoliving.co.nz/ nzsecurity/mag/August-September2000/ THE\%2OHISTORY\%20OF\%20CORRUPTION.htm Accessed $26^{\text {th }}$ February 2002.

Transparency International. 200I. Press release: new index highlights worldwide corruption crisis, says Transparency International. [Online]. http://www.transparency.org/cpi/200I/cpi200I.html Accessed 6 th February 2002.

Turmex Trading (2001). Constitution of the State of Florida: the 2000 Florida Statutes: Florida Law Manual on corruption. [Online]. http://www.artdecolive.com/ government/corruption.htm Accessed $27^{\text {th }}$ February $27^{\text {th }} 2002$.

Twining, J. 200I. Bibliometrics - an overview. [Online]. Available at the University of Denver Website: $h t t p: / / w w w . d u . e d u /$ -jtwining/LIS4326/bibliometrics.htm Accessed $17^{\text {th }}$ April 2002.

United Nations, Crime Prevention and Criminal Justice Division. 1997. United Nations action against corruption and bribery. [Online]. http//uncjin.org/Documents/ corrupt.htm Accessed 4th March 2002.

United Nations Office for Drug Control and Crime Prevention. 200I. Corruption. [Online]. http://www.undcp.org/ corruption.html Accessed 6 th March 2002.

The United States Agency for International Development (2000). Anti-corruption resources: what is corruption? http:// www.usaid.gov/democracy/anticorruption.html Accessed $6^{\text {th }}$ February 2002

Wallace, D. P. (1989). Bibliometrics and citation analysis. principles and applications of information science for library professionals. Chicago: American Library Association, 10-26.

Ward, P.L. 1997. The nature of UK research literature: some thoughts arising from a bibliometric study. Proceedings of the 63rd
IFLA Conference. August 3 Ist-Septem IFLA Conference, August 3/ st-September 15. http://www.ifla.org/IV/ifla63/63layp.htm Accessed $20^{\text {th }}$ March 2002.

Warigi, G. (2001). East and East-Central Africa. In: Hodess, R., Banfield, J., \& Wolfe, T., (Eds.). Global corruption report. Berlin, Transparency International, 81-94. http://www.globalcorruptionreport.org/download/rr_wwc_africa.pdf Accessed on I2 ${ }^{\text {th }}$ March
2002.

Williams, R. 1987. Political corruption in Africa. $2^{\text {nd }}$ ed. Hampshire: Dartmouth.

Yitzhaki, M. \& Shahar, T. 2000. The emergence of alternative medicine as a new field: a bibliometric study of a rapidly-growing field. Proceedings of the 66th IFLA Council and General Conference, Jerusalem, Israel 13-18 August. Available at the IFLA Website: $h t t p: / / w w w . i f l a . o r g / / V / i f l a 66 / p a p e r s / 055-/ 27 e . h t m$ Accessed $4^{\text {th }}$ April 2002.

\section{Declaration and acknowledgement}

Different versions of this paper have been presented at the ProLISSA/DISSAnet Conference, Pretoria 2002 and at the $9^{\text {th }}$ International Conference on Scientometrics and Informetrics (ISSI) as well as the COLLNet Meeting, Beijing, China, 25 th $30^{\text {th }}$ August 2003. The University of Zululand Research Committee is acknowledged for funding participation of one of the authors at the $9^{\text {th }}$ ISSI Conference. 